\title{
Differentiated Vascular Myocytes: Are They Involved in Neointimal Formation?
}

Bruce Holifield, Thorunn Helgason, Sandra Jemelka, Addison Taylor, Stephen Navran, Julius Allen, and Charles Seidel

Department of Medicine, Section of Cardiovascular Sciences, Baylor College of Medicine, Houston, Texas 77030

\begin{abstract}
The role of differentiated vascular myocytes in neointimal formation in canine carotid artery was investigated. Using antibodies and cDNA probes, cells were characterized in situ and after isolation. In situ characterization indicated the majority of medial cells expressed both smooth muscle myosin and alpha actin but many cells were negative to these markers. All adventitial cells were negative for these proteins. The muscle protein-positive cells were designated differentiated, vascular myocytes (VSMC). The others were designated type 2 cells. Sequential enzyme digestion from the lumenal surface yielded VSMC $(>90 \%)$ while digestions from the adventitial surface yielded type 2 cells $(>90 \%)$. VSMC were viable in culture but did not spread, proliferate, or alter expression of muscle proteins. Type 2 cells proliferated and increased their expression of muscle actin but did not express muscle myosin. Characterization of neointimal cells from injured carotid arteries indicated they were morphologically and immunologically identical to cultured type 2 cells. We concluded that: $(a)$ canine carotid artery media consists of a heterogeneous cell population; (b) serum does not stimulate isolated VSMC to undergo phenotypic modulation or proliferate; and (c) type 2 cells may be responsible for neointimal formation because they proliferate and acquire a phenotype identical to in situ neointimal cells. (J. Clin. Invest. 1996. 97:814-825.) Key words: myosin • actin • vascular smooth muscle • neointima - tissue culture
\end{abstract}

\section{Introduction}

Morphological examination of mammalian muscular and elastic arteries at the light and electron microscopic levels (1) suggests that the media is composed of a single cell type, the smooth muscle cell. This is in contrast to avian arteries where two distinct cell populations have been described $(2,3)$, one with morphological characteristics of muscle cells (large numbers of myofilaments, attachment bodies, peripheral vesicles, and a basement membrane) and a second population lacking these characteristics.

The cellular homogeneity of mammalian arterial media implies that the smooth muscle cell must be responsible not only

Address correspondence to Dr. Charles Seidel, Dept. of Medicine, Section of Cardiovascular Sciences, Baylor College of Medicine, One Baylor Plaza, Houston, TX 77030. Phone: 713-798-4877; FAX: 713790-0681.

Received for publication 22 March 1995 and accepted in revised form 27 October 1995.

J. Clin. Invest.

(C) The American Society for Clinical Investigation, Inc.

0021-9738/96/02/0814/12 \$2.00

Volume 97, Number 3, February 1996, 814-825 for changing vessel diameter by modulating contractile activity but also for structural remodeling of the medial layer under normal and pathological conditions (4). This remodeling includes synthesis and secretion of extracellular matrix proteins as well as the formation of atherosclerotic plaques and neointimal thickening. Unlike striated muscle cells that are terminally differentiated, vascular smooth muscle cells (VSMC) ${ }^{1}$ from adult mammals are considered to retain the ability to proliferate in response to a variety of chemical and physical stimuli. This proliferative capacity also contributes to vascular wall remodeling. These characteristics of VSMC form the basis of the "injury" hypothesis for atherosclerosis $(5,6)$. According to this hypothesis, phenotypic modulation of the medial smooth muscle cell accounts in part for the presence of cells with different characteristics within atherosclerotic plaques and the neointima. During the two decades since this hypothesis was first proposed, a considerable amount of supportive evidence has accumulated. However, data have also accumulated suggesting that the medial layer of a normal vessel may not be composed of a single cell type.

Two types of cellular heterogeneity exist within the media. One type involves the smooth muscle cell itself. Cells expressing smooth muscle alpha actin or myosin heavy chain and, presumably, smooth muscle cells are not homogeneous with respect to expression of other proteins. Immunocytochemical data indicate that alpha actin-positive medial cells in rat aorta may be positive to vimentin, desmin, or both (7). Zanellato et al. (8) have shown in bovine aorta that some medial cells are positive to a smooth muscle myosin heavy chain antibody while others are positive to antibodies to both muscle and nonmuscle myosins. In addition, a cell population that expresses exclusively a fetal form of smooth muscle myosin heavy chain (9) has been identified in adult bovine aortic media.

The second type of cellular heterogeneity involves the presence of "nonmuscle" cells. Evidence indicates that the media contains cells that are negative to muscle actin (10) and myosin heavy chain (8) antibodies. These cells have been estimated to represent $8-14 \%$ of all cells freshly isolated from adult rat aorta $(11,12)$. Such nonmuscle cells may be macrophages or lymphocytes; however, their high frequency in normal vessels and their lack of reactivity to monocyte/macrophage antibodies (13) suggest that they do not represent inflammatory cells. Studies also indicate that subpopulations of cells can be obtained from morphologically homogeneous aortic media that, when cultured, grow at different rates (10), have distinct morphologies that are retained with subculturing (14), or have different substrate adhesive properties (15). Such examples of medial cell heterogeneity have led to the suggestion (16) that these subpopulations may have specific functions within the vessel wall. The existence of medial cell heterogene-

1. Abbreviations used in this paper: DAPI, 4',6-diamidino-2-phenylindole, $\mathrm{HCl}$; DIC, differential interference contrast; VSMC, vascular smooth muscle cells. 
ity does not preclude phenotypic modulation but may mean that not all cells would exhibit modulation.

The hypothesis that formed the basis of this study is that if phenotypic modulation of smooth muscle cells is responsible for neointimal formation after balloon catheter injury, then smooth muscle cells isolated from the lumenal surface of normal vessels, the most likely source of neointimal cells, should undergo phenotypic modulation in culture. The canine carotid artery was selected for study because its large size permitted systematic enzyme dispersion and isolation of cells from sequential layers of the media. Using specific antibodies to cytoskeletal proteins and cDNA probes, cells in situ, freshly isolated cells, and cells in culture were characterized. The results suggest that the media of canine carotid artery is composed of at least two cell populations and that only one of these cell types, initially negative for muscle proteins, proliferates and undergoes phenotypic modulation.

\section{Methods}

Cell isolation and culturing. Carotid arteries were obtained from adult mongrel dogs of either sex under aseptic conditions. The vessels were digested while under pressure in a manner similar to that described by Warshaw et al. (17). Under a tissue culture hood adhering fat and superficial connective tissue were removed and the vessel everted or left right-side-out. One end was ligated with surgical silk and the other end cannulated with an 18-gauge needle. Sterile Hanks' balanced salt solution was then injected into the vessel with a syringe until a pressure of $\sim 100 \mathrm{mmHg}$ was attained as indicated by an attached mercury manometer. The vessel was ligated below the end of the needle so that the vessel remained inflated after withdrawing the needle. The ends of the vessel were securely covered with plastic wrap. The inflated carotid segment was placed in a sterile flask containing $15 \mathrm{ml}$ of a mixture of collagenase $1.25 \mathrm{mg} / \mathrm{ml}(200 \mathrm{U} / \mathrm{mg})$, elastase $0.125 \mathrm{mg} / \mathrm{ml} \mathrm{(90-95} \mathrm{U/mg),} \mathrm{trypsin} \mathrm{inhibitor} \mathrm{(type} \mathrm{I)} 0.38 \mathrm{mg} /$ $\mathrm{ml}$, bovine albumin $2 \mathrm{mg} / \mathrm{ml}$, and Hepes $3.58 \mathrm{mg} / \mathrm{ml}(\mathrm{pH} \mathrm{7.4)}$ and incubated in an agitating water bath at $37^{\circ} \mathrm{C}$ for specific times. At the end of each incubation period, the enzyme solution was removed, fresh solution was added, and the incubation was continued. The released cells were spun out of the enzyme solution and the resulting pellet was washed once with phosphate-buffered saline.

In studies designed to correlate the extent of wall digestion with the characteristics of the released cells, after each digestion period a 10-mm-long segment was cut from the vessel for histology and the remaining vessel was reinflated before being returned to the digestion solution. The tissue segment was immediately placed in $3.7 \%$ formaldehyde for routine histology.

Cells to be placed in culture were resuspended in Dulbecco's modified Eagle's medium (GIBCO-BRL, Gaithersburg, MD) containing $1 \%$ glutamine, $3 \%$ PSN $(300 \mu \mathrm{g} / \mathrm{ml}$ of penicillin, streptomycin, and neomycin), and 5\% gentamicin plus specific concentrations of fetal bovine serum (Hyclone Laboratories, Logan, UT) or fresh serum prepared from the dog whose vascular cells were being studied. An aliquot of suspended cells was taken for cell counting (hemocytometry) and the remainder was seeded into appropriate tissue culture dishes.

To determine the effect of extracellular matrix on seeding efficiency and cell morphology, 35-mm tissue culture dishes were coated with type I rat tail collagen (Collaborative Research Inc., Bedford, MA) before being seeded with cells. A $200-\mu \mathrm{l}$ volume of a $1.5 \mathrm{mg} / \mathrm{ml}$ solution of collagen was spread on the surface of the dish and allowed to air dry overnight in the tissue culture hood. This resulted in a fibrous deposit of collagen strands on the surface of the dish that could be visualized under the microscope. The dishes were rinsed with distilled water and culture medium before plating cells.

Culture dishes were maintained in a standard humidified tissue culture incubator maintained at $37^{\circ} \mathrm{C}$ and equilibrated with $5 \% \mathrm{CO}_{2}$ and $95 \%$ air.

Tissue sections. Formaldehyde-fixed vessel rings were paraffin embedded, sectioned, and processed for routine histology. Sections were stained with a trichrome stain to visualize cytoplasm, cell nuclei, and extracellular matrix material.

Tissue to be used for immunohistochemistry was placed in plastic boats containing OTC frozen tissue embedding medium (Fisher Scientific Co., Fair Lawn, NJ) and frozen in liquid nitrogen. Cross sections 5- $\mu \mathrm{m}$ thick were cut and transferred to glass slides and kept at $-20^{\circ} \mathrm{C}$ until processed for immunohistochemistry.

Immunohistochemistry. Cells to be labeled for immunohistochemistry were seeded onto coated (type 1 collagen) or noncoated glass coverslips $(20 \mathrm{~mm})$ and either fixed within $8 \mathrm{~h}$ of seeding or maintained in culture for a specific time before being fixed. Cells were fixed for $30 \mathrm{~min}$ at room temperature in $3.7 \%$ formaldehyde prepared in PBS, washed twice with PBS, and then permeabilized by a 3-min exposure to a $0.1 \%$ Triton X-100/PBS solution. The cells were washed with PBS and blocked for 30 min with a PBS solution containing 1\% fish gelatin (Sigma Immunochemicals, St. Louis, MO), $1.5 \%$ bovine albumin, and $0.5 \%$ Tween 20 . Primary antibody, at a dilution of 1:100 in blocking solution, was added, incubated with the cells for $30 \mathrm{~min}$ at room temperature, and then removed with blocking solution. Secondary antibody, at a dilution of 1:50 in blocking solution, was added to the coverslips for an additional $30 \mathrm{~min}$. The secondary antibody was washed off with blocking solution and then PBS before mounting the coverslips on glass slides with polyvinyl alcohol containing $n$-propylgalate as an antifade agent.

Frozen tissue sections were plunged, while still frozen, into room temperature formaldehyde (3.7\% in PBS) and fixed for $30 \mathrm{~min}$. Permeabilization, blocking, and antibody incubations were identical to those used for single cells.

The smooth muscle myosin heavy chain antibody was a monoclonal antibody prepared in this laboratory using purified rabbit uterine myosin heavy chain as the antigen (18). The antibody cross-reacts with both smooth muscle myosin heavy chains (SM-1 and SM-2) but not with nonmuscle or striated muscle myosins (19). The nonmuscle myosin heavy chain antibody, a polyclonal antibody to platelet myosin, was obtained from Biomedical Technologies, Inc. (Stoughton, MA). The smooth muscle alpha actin and vimentin antibodies were monoclonal antibodies obtained from Sigma Immunochemicals. The antibody to the Na pump is to the alpha subunit and reacts with all three isoforms (20). Fluorescent secondary antibodies were obtained from either Bio-Rad (Richmond, CA) or Jackson ImmunoResearch Laboratories, Inc. (West Grove, PA). To label cell nuclei 4',6-diamidino-2-phenylindole, $\mathrm{HCl}$ (DAPI; Molecular Probes, Inc., Eugene, OR) was used at a concentration of $1 \mu \mathrm{g} / \mathrm{ml}$ in blocking solution.

Phase and digital imaging microscopy. Routine phase-contrast photomicrographs were made with a Nikon Diaphot inverted phase microscope equipped with a 35-mm camera. An Axiophot microscope equipped with a DAGE CCD-72 video camera and a DSP-200 signal processor (DAGE MT-1) was used for digital imaging microscopy. Images at magnifications of either 20 or 40 were digitized using a TARGA-64+ video board connected to a 486 microprocessor running at $66 \mathrm{mHz}$. Digital images were collected using the video camera in manual mode. For each digital fluorescence image a companion background image was collected and subtracted using Adobe Photoshop on a Macintosh Centris 660 computer. The resulting signal was contrast enhanced to cover the full 8-bit range of the digital image. The processed monochrome images were pseudocolored by loading into RGB color channels. Some digital images were assembled into montages containing antigen immunofluorescence images in the red color channel and images of DAPI-labeled nuclei in the green and blue channels. Image segmentation was used to extract distributions of the nuclei of antigen-negative cells (see Figs. $7 E$ and $10 D$ ). Selection of these nuclei was accomplished by defining an antigen-negative cell as one with a nucleus that did not overlap the fluorescence signal of the antigen. Overlap was detected by subtracting antigen image 
from the DAPI image, altering the morphology and intensity of overlapping nuclei. These nuclei were identified by comparisons of binary maps and were deleted from the DAPI montage, leaving in place the nuclei of antigen-negative cells.

Gel electrophoresis. To assess the type of myosin heavy chains expressed by cells in culture, myosin isoforms in cell extracts were separated by one-dimensional PAGE. The extraction of myosin heavy chains and the gel electrophoresis procedure were identical to previously published methods $(18,19)$.

Northern analysis and RT-PCR. Total RNA was isolated from cells using RNAzol (Biotecx Laboratories, Houston, TX) according to the manufacturer's instructions. Total RNA was run on $1 \%$ agarose-formaldehyde gels and transferred to nylon membranes by overnight capillary transfer. The RNA was fixed to the membrane using a UV Stratalinker 1800 , incubated in $20 \mathrm{ml}$ of prehybridization solution for $3 \mathrm{~h}$ at $42^{\circ} \mathrm{C}$, and then overnight at $42^{\circ} \mathrm{C}$ in a similar solution containing the radioactively labeled cDNA probe. The prehybridization and hybridization solutions contained $50 \%$ formamide, $5 \times$ SSC, $5 \times$ Denhardt's, $25 \mathrm{mM}$ sodium phosphate (pH 7.0), 0.1\% SDS, and 250 $\mu \mathrm{g} / \mathrm{ml}$ salmon sperm DNA. To remove nonspecific radioactivity, the membrane was washed twice ( $15 \mathrm{~min}$ each) in $2 \times$ SSC plus $0.1 \%$ SDS at $55^{\circ} \mathrm{C}$ and twice $(15 \mathrm{~min}$ each) in $0.2 \times \mathrm{SSC}$ plus $0.1 \%$ SDS before being placed under film for periods up to $1 \mathrm{wk}$. A single membrane was probed repeatedly by removing the previous label by incubating the membrane for $3 \mathrm{~h}$ at $65^{\circ} \mathrm{C}$ in a $50 \%$ formamide, $25 \mathrm{mM}$ sodium phosphate ( $\mathrm{pH}$ 6.5) solution followed by two 15 -min washes at room temperature in $2 \times \mathrm{SSC}, 0.1 \%$ SDS.

The smooth muscle myosin heavy chain probe (provided by Dr.
M. Periasamy, University of Cincinnati, Cincinnati, $\mathrm{OH}$ ) was a $1.5-\mathrm{kb}$ cDNA for the carboxy-terminal sequence of the molecule (21). It does not recognize brain myosin mRNA nor the nonmuscle myosin present in canine type 2 cells (this study, see Fig. 6). The SM22 cDNA was a 1-kb probe (provided by Dr. Eric Olson, University of Texas, Houston, TX) prepared against rat SM22 (22). Each membrane was also labeled with a $1.1-\mathrm{kb}$ probe to $18 \mathrm{~S}$ ribosomal RNA to indicate the level of RNA loading. All cDNA probes were labeled with $\left[{ }^{32} \mathrm{P}\right] \mathrm{CTP}$ using a random primer kit according to manufacturer's instructions (Boehringer Mannheim Corp., Indianapolis, IN).

$R T-P C R$. Total RNA prepared as described above was converted to cDNA by incubating $5 \mu \mathrm{g}$ of RNA with a mixture of random primers, nucleotides, and reverse transcriptase in a total volume of $20 \mu \mathrm{l}$ according to manufacturer's instructions (Promega, Madison, WI). A $10-\mu l$ aliquot of this mixture was then used for the PCR reaction using Taq DNA polymerase (Promega) and SM22 primers (provided by Dr. Eric Olson) developed for mouse in a total reaction mixture of $100 \mu \mathrm{l}$. Reaction conditions were $1 \mathrm{~min}$ at $95^{\circ} \mathrm{C}, 30 \mathrm{~s}$ at $62^{\circ} \mathrm{C}$, and $30 \mathrm{~s}$ at $72^{\circ} \mathrm{C}$ for 30 cycles. A $15-\mu 1$ aliquot of the PCR product was run on a $1 \%$ agarose $/ 1 \%$ Nusieve gel adjacent to a DNA sizing ladder and visualized by staining with ethidium bromide.

Cell viability. Cell viability was assessed in two ways. Membrane integrity was assessed by determining the number of cells that excluded trypan blue as described previously (19). In addition, a live/ dead assay was used (Molecular Probes, Inc.). This assay consists of calcein AM, a fluorogenic substrate that is cleaved only in viable cells to form a green fluorescent membrane-impermeant product, and ethidium homodimer-1, which passes only through the membranes of

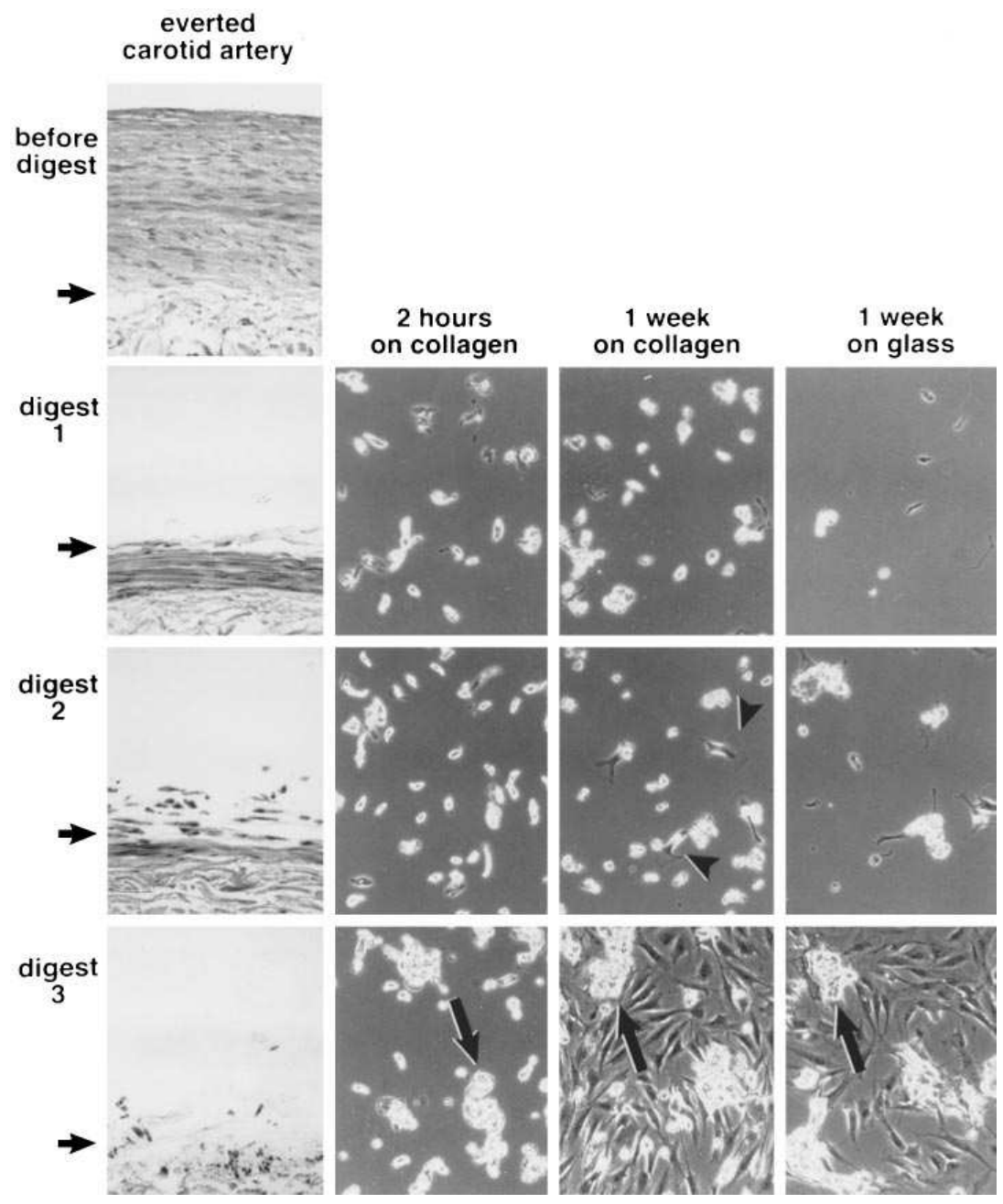

everted

digest

1 


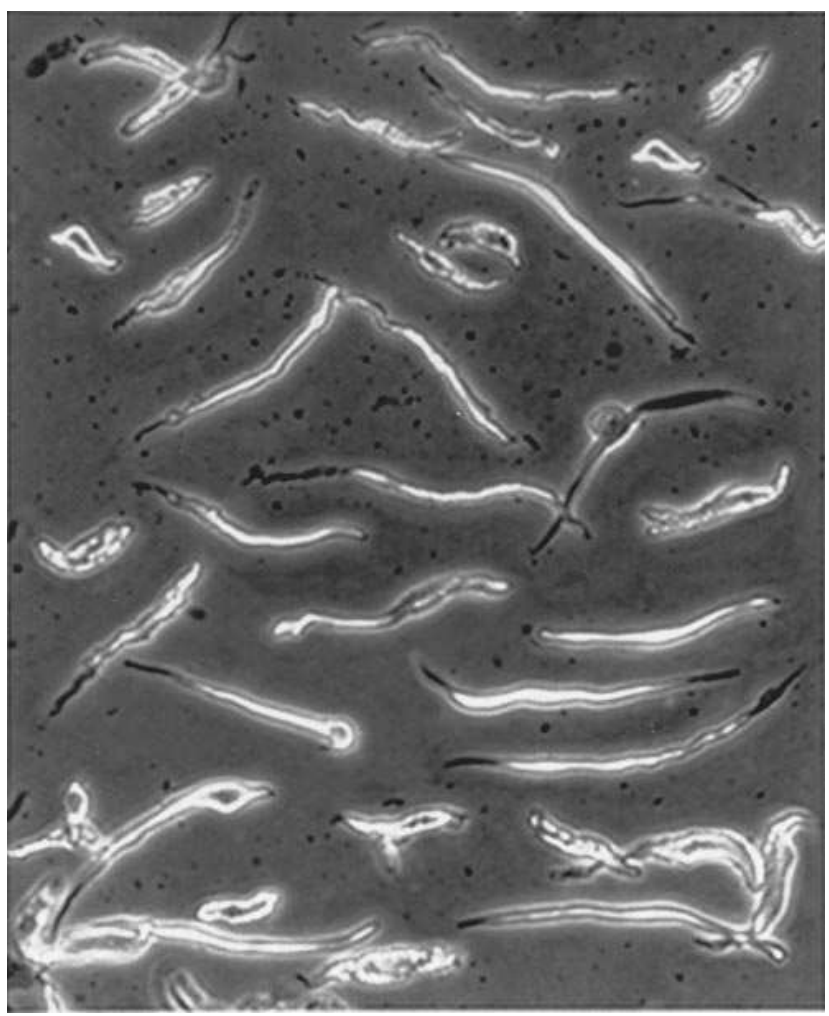

Figure 2. Phase-contrast photomicrograph of type 1 cells fixed while still in enzyme immediately after release by a 30-min digestion of an everted carotid artery. The cells are long and fusiform in shape, characteristics of VSMC.

dead cells and labels the DNA red. The kit was used according to manufacturer's instructions. The number of total cells in a field was counted under bright-field illumination and then the number of green (live) and red (dead) cells was determined in the same field using the appropriate fluorescent filters.

$\left[{ }^{3} H\right]$ Thymidine labeling. Freshly isolated cells were seeded into 24-well dishes and maintained for $24 \mathrm{~h}$ in medium containing $0.1 \%$ fetal bovine serum. On the second day the medium was either refreshed or switched to one containing $0.5,1$, or $10 \%$ fetal bovine serum or $10 \%$ autologous dog serum. On the third day the medium was replaced with identical medium containing $\left[{ }^{3} \mathrm{H}\right]$ thymidine $(2.5 \mu \mathrm{Ci} / \mathrm{ml})$ and incubated for an additional $24 \mathrm{~h}$. At the end of this time the medium was removed, and the cells were washed twice with PBS and twice with $10 \%$ trichloroacetic acid to precipitate cell protein. The protein was dissolved in $0.5 \mathrm{~N}$ sodium hydroxide by overnight incubation at room temperature. The solution was neutralized with glacial acidic acid and an aliquot was taken for scintillation counting.

${ }^{86} \mathrm{Rb}$ uptake. To assess the ability of the isolated cells to establish and maintain transmembrane ion gradients, the activity of the $\mathrm{Na}^{+}$$\mathrm{K}^{+}$pump was assessed by determining the rate of ouabain-sensitive ${ }^{86} \mathrm{Rb}$ uptake using previously published methods (23). Freshly isolated VSMC were washed twice in an incubation buffer containing (mM): $120 \mathrm{NaCl}, 5 \mathrm{KCl}, 1 \mathrm{MgCl}_{2}, 2 \mathrm{CaCl}_{2}$, and $20 \mathrm{Hepes}$ adjusted to $\mathrm{pH} 7.4$ with Tris base. The cells were incubated for 30,60, or $120 \mathrm{~min}$ at $37^{\circ} \mathrm{C}$ in $1 \mathrm{ml}$ of buffer and uptake was initiated by adding a trace amount of ${ }^{86} \mathrm{Rb}(2-3 \mu \mathrm{Ci}$; New England Nuclear, Boston, MA) for the last $10 \mathrm{~min}$. Previous work indicated that uptake was linear over $10 \mathrm{~min}$. Incubations were stopped by layering the $1 \mathrm{ml}$ of buffer on top of $0.5 \mathrm{ml}$ of oil and spinning the cells through the oil to remove extracellular radioactivity. The pelleted cells were lysed in water and the radioactivity was quantitated by Cerenkov counting. A parallel set of cells was run to determine ouabain-insensitive ${ }^{86} \mathrm{Rb}$ uptake, which is that observed in the presence of $1 \mathrm{mM}$ ouabain (added $5 \mathrm{~min}$ before $\mathrm{Rb}$ ). Ouabain-sensitive uptake was calculated as the difference between total uptake and ouabain-insensitive uptake.

To determine the effect of an elevation in intracellular $\mathrm{Na}$ content on pump activity, cells were incubated as described above but the buffer did not contain $\mathrm{KCl}$. In the absence of extracellular $\mathrm{K}$ ions, the pump is inhibited and intracellular Na concentration is elevated.

Induction of neointimal formation. Four mongrel dogs of either sex that were free of heart worms were anesthetized with Na pentobarbital $(30 \mathrm{mg} / \mathrm{kg})$ and, using sterile surgical procedures, the lingual artery was exposed on the right side. A Fogarty 5 French angioplasty balloon $(1 \mathrm{ml})$ catheter was inserted into the artery and advanced while deflated into the common carotid artery and then into the aorta. When the catheter entered the aorta the balloon was inflated with $0.7 \mathrm{ml}$ of saline and withdrawn just to the junction with the lingual artery, at which point it was deflated. This procedure was repeated two more times before removing the catheter. The lingual artery was ligated and the muscle and skin layers were closed. Prophylactic antibiotic treatment was given and the animals were examined daily until the time for vessel harvest $(1,4,7$, and $14 \mathrm{~d})$. At the time of vessel harvest the animals were anesthetized and both the injured and contralateral control common carotid arteries were removed and cut into rings. Three rings from different locations along the vessel were imbedded in paraffin and three other rings were frozen in OTC as described above.

\section{Results}

Pressurized, everted carotid arteries were subjected to sequential 30-min enzyme digestions until they deflated. The appearance of the vessel wall and the released cells from three sequential digestions is illustrated in Fig. 1. The first digestion yielded large bipolar cells that represented $>95 \%$ of the cells present in the isolate. Immediately upon isolation, these cells were fusiform (Fig. 2; $250 \mu \mathrm{m}$ long $\times 30 \mu \mathrm{m}$ at the widest point) but shortened (80-100 $\mu \mathrm{m}$ long $\times 40-50 \mu \mathrm{m}$ wide $)$ when placed in culture medium (Fig. 3 ). With continued digestion through the wall, the number of bipolar cells decreased and a second population of small (10-20 $\mu \mathrm{m}$ diameter) spherical cells became dominant (Figs. 1 and 3 ). They were the only cells present in the final digest.

The relative numbers of these two cell types reversed when pressurized; right-side-out carotid arteries were subjected to sequential enzyme digestion. Initial digestions contained only small spherical cells while deeper digestions yielded an ever increasing number of large bipolar cells (data not shown).

For convenience the large fusiform cells that dominated the media were designated type 1 cells, and the small spherical cells that dominated the adventitia were designated type 2 cells. These two cell types were further characterized.

Type 1 cells adhered poorly to tissue culture plastic or glass even when coated with serum. However, they attached well to collagen-coated surfaces. Type 2 cells adhered well to both coated and noncoated surfaces. This difference is illustrated in Fig. 1. The number of type 1 cells remaining in culture after 1 wk was much less if they were seeded onto glass compared with seeding onto a collagen-coated surface or compared with type 2 cells seeded onto either type of surface. In addition, type 1 cells did not spread extensively while in culture compared with type 2 cells. Fig. 3 illustrates the shape changes that type 1 and 2 cells underwent during the first $24 \mathrm{~h}$ in culture. Within $24 \mathrm{~h}$, type 2 cells began to spread by sending out numerous membrane projections. This did not occur with the type 1 cells. 


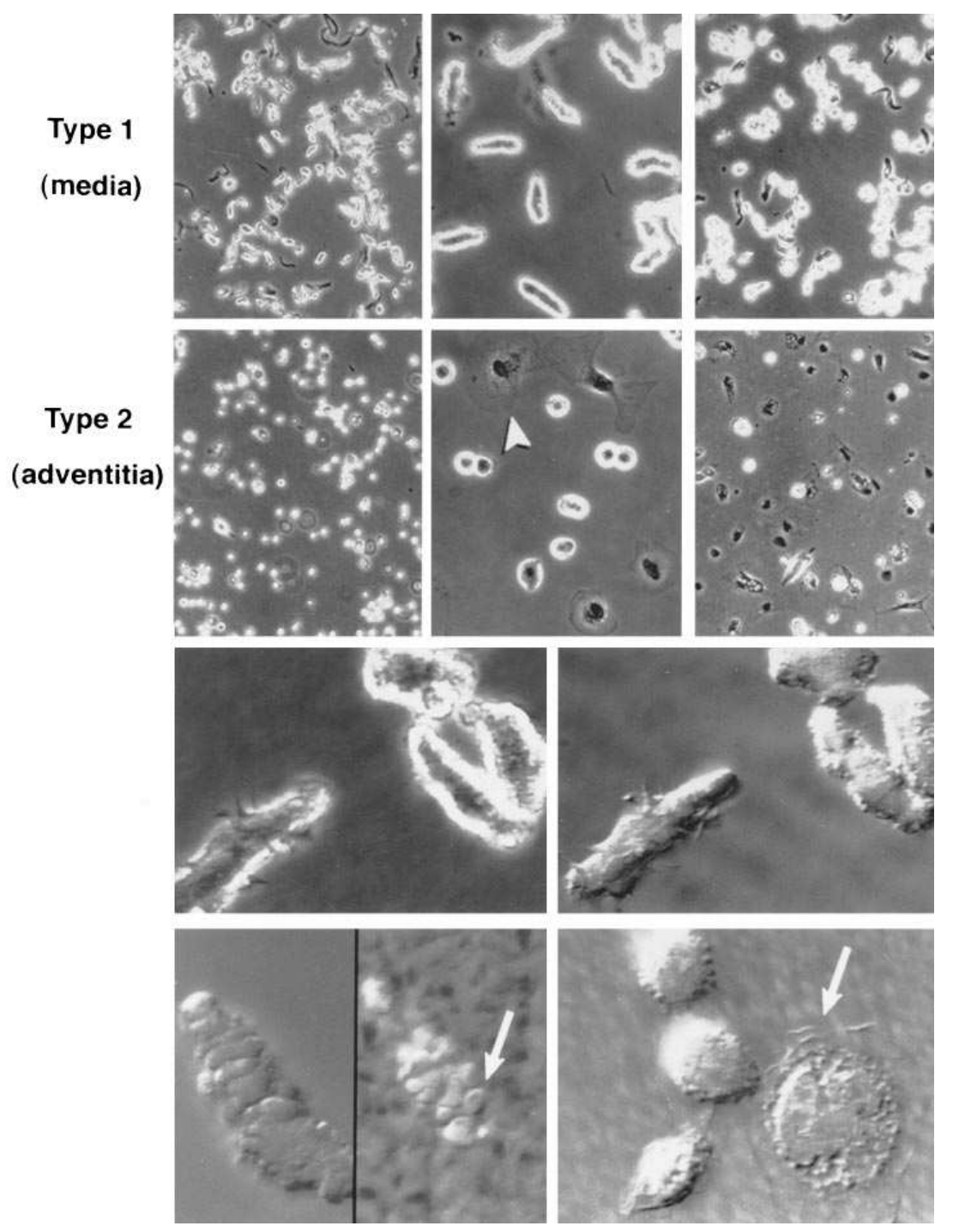

Figure 3. Photomicrographs of type 1 and type 2 cells illustrating changes in morphology with time in culture and the extent of cell-substrate interaction. Photomicrographs illustrate type 1 and type 2 cells after $2 \mathrm{~h}$ (first column, $\times 10$; and second column, $\times 20)$ or $24 \mathrm{~h}($ third column, $\times 10)$ in culture. Type 1 cells are bipolar and do not spread while type 2 cells are small spherical cells that spread readily in culture (arrowhead). Photomicrographs in the third and fourth rows illustrate protrusive membrane activity in these two cell types by differential interference contrast (DIC) microscopy. The paired images (third row) are of type 1 cells in phase-contrast (left) or DIC (right). Note the small number of membrane protrusions. In the fourth row, type 1 (left) and type 2 cells (right) are shown by DIC taken at the cell-substratum junction. Type 1 cells make few cell-substrate contacts (arrow, left) while type 2 cells have extensive membrane protrusions (arrow, right).
Type 1 cells did not proliferate in culture while type 2 cells readily proliferated. Table I indicates that fetal bovine serum did not stimulate thymidine uptake by type 1 cells while it did in type 2 cells. Raising the serum concentration to $50 \%$, adding basic fibroblast growth factor to the standard culture medium, or using autologous dog serum (data not shown) also did not

Table I. Thymidine Labeling of Type 1 and Type 2 Cells

\begin{tabular}{lllll}
\hline \multicolumn{2}{c}{ Type 1 cells } & & \multicolumn{2}{c}{ Type 2 cells } \\
\cline { 1 - 2 } \cline { 5 - 5 } Mitogen & Thymidine & & Mitogen & Thymidine \\
\hline $0.5 \%$ FBS & $1.0 \pm 0.1$ & & $0.5 \%$ FBS & $4.3 \pm 1.4^{*}$ \\
$1.0 \%$ FBS & $0.9 \pm 0.1$ & & $1.0 \%$ FBS & $2.7 \pm 0.8^{*}$ \\
$10 \%$ FBS & $0.9 \pm 0.1$ & & $10 \%$ FBS & $1.9 \pm 0.3^{*}$ \\
& & & \\
\hline
\end{tabular}

Thymidine labeling expressed as a multiple of the labeling in $0.1 \%$ FBS. All values are means \pm SEM. The number of experiments equals 4-6, and in each experiment triplicate determinations were made and averaged for each experimental value. ${ }^{*} P<0.05$ relative to values for Type 1 cells. stimulate proliferation of type 1 cells. Type 1 cells did not increase in number in culture while type 2 cells reached confluence within $10 \mathrm{~d}$. Type 2 cells appeared more sensitive to low serum concentrations $(0.5 \%)$ than to high concentrations $(10 \%)$; however, these differences were not significantly different.

Type 1 cells had a selectively permeable cell membrane based on the observation that $>80 \%$ of the cells excluded trypan blue or were alive based on the live/dead assay. Finally, they exhibited a ouabain-sensitive Rb uptake that was stimu-

Table II. Type 1 Cell Ouabain-sensitive ${ }^{86}$ Rb Uptake ( $\mathrm{nmol} / 10^{5}$ cells $\left./ 10 \mathrm{~min}\right)$

\begin{tabular}{rcc}
\hline \multicolumn{1}{c}{ Time } & Control & Zero $K_{\text {o }}$ preincubation \\
\hline $30 \mathrm{~min}$ & $4.9 \pm 0.4(8)$ & $6.2 \pm 1.1(4)$ \\
$60 \mathrm{~min}$ & $2.2 \pm 0.5(6)^{*}$ & $5.8 \pm 0.8(4)^{\ddagger}$ \\
$120 \mathrm{~min}$ & $1.0 \pm 0.3(7)^{*}$ & $3.0 \pm 0.9(5)^{\ddagger}$
\end{tabular}

${ }^{*} P<0.05$ relative to $30 \mathrm{~min} ;{ }^{\ddagger} P<0.05$ relative to control. 
non-muscle myosin
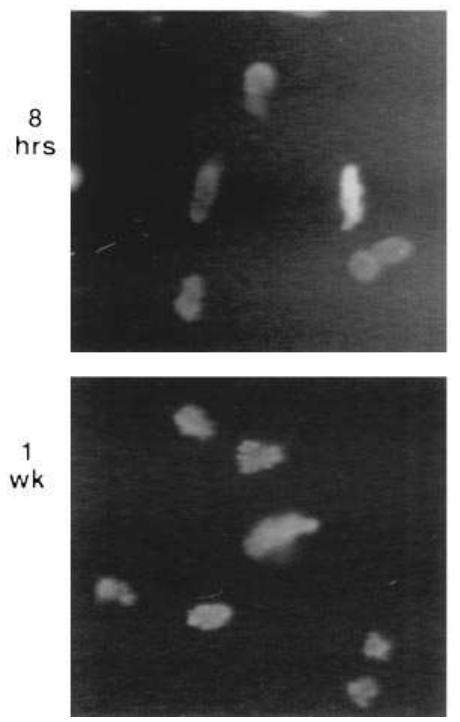

(t -actin
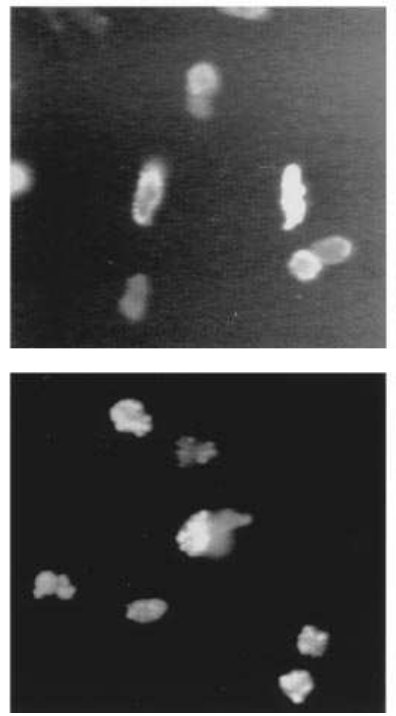

non-muscle mvosin
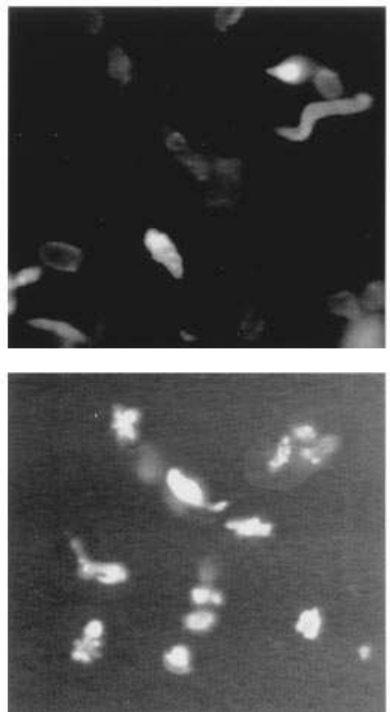

smooth muscle myosin
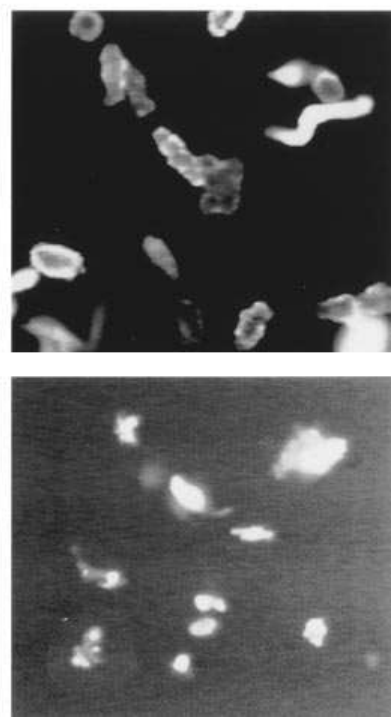

Figure 4. Photomicrographs of double antibody-labeled type 1 cells after $8 \mathrm{~h}$ (first row) and $1 \mathrm{wk}$ (second row) in culture. The first antibody pair is (left to right) to nonmuscle myosin heavy chain and alpha actin. The second antibody pair is (left to right) to nonmuscle myosin and smooth muscle myosin heavy chains. Type 1 cells express all three proteins at the time of isolation and after $1 \mathrm{wk}$ in culture.

lated by increasing intracellular $\mathrm{Na}$ (incubation in zero extracellular K concentration) (Table II) suggesting that they had a functioning Na-K pump that could establish and maintain a transmembrane ion gradient.

Type 1 cells expressed smooth muscle myosin heavy chain and alpha actin (Fig. 4) immediately ( $8 \mathrm{~h}$ ) after isolation as well as after $1 \mathrm{wk}$ in culture. Based on SDS-PAGE, the amount of smooth muscle myosin heavy chain expressed did not change over $1 \mathrm{wk}$ in culture or relative to the amount of nonmuscle myosin expressed (see Fig. 6 C). In contrast, type 2

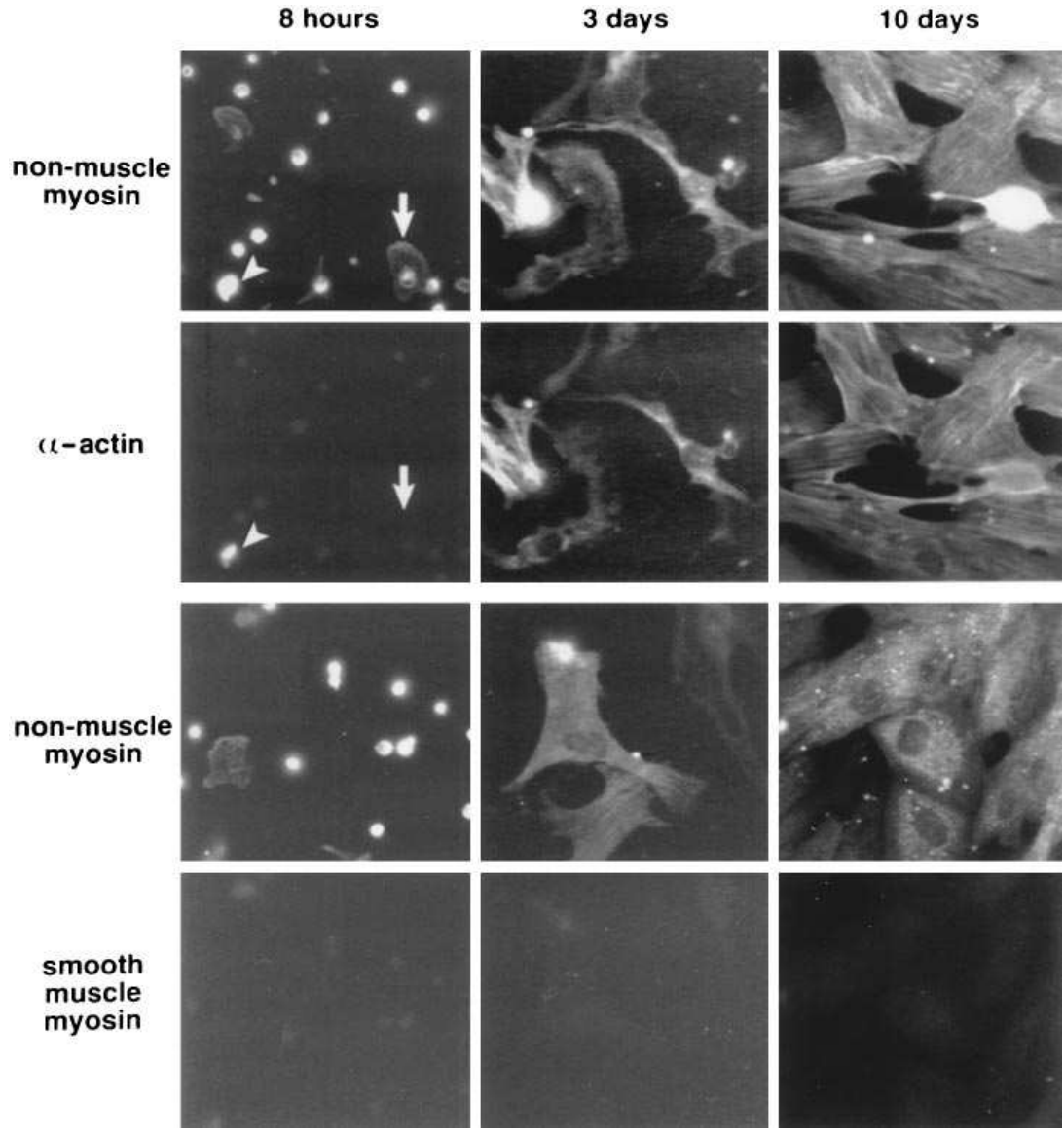

Figure 5. Photomicrographs of double antibodylabeled type 2 cells after $8 \mathrm{~h}, 3 \mathrm{~d}$, and $10 \mathrm{~d}$ in culture. The first antibody pair is to nonmuscle myosin heavy chain and alpha actin. The second antibody pair is to nonmuscle myosin and smooth muscle myosin heavy chains. Initially $(8 \mathrm{~h})$, type 2 cells were negative to alpha actin (arrow indicates typical pattern of labeling) but the level of expression increased with time in culture. However, there was the infrequent cell (arrowhead) that was initially positive to alpha actin. Nonmuscle myosin was expressed at all times. At no time in culture did type 2 cells express smooth muscle myosin. 
MHC
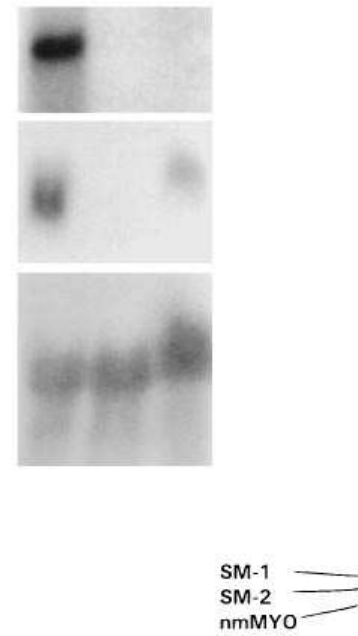

C.

SDS-PAGE

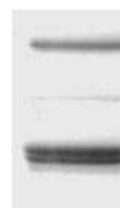

Figure 6. Message and protein levels of type 1 and type 2 cells. $(A)$ Expression of smooth muscle myosin heavy chain $(\mathrm{MHC})$ and SM22 mRNA and $18 \mathrm{~S}$ ribosomal RNA in freshly isolated type 1 cells (lane 1 ), freshly isolated type 2 cells (lane 2 ), and confluent type 2 cells (lane 3). $30 \mu \mathrm{g}$ of total RNA was loaded into each lane. (B) Ethidium bromide-stained gel of RT-PCR products generated from total RNA isolated from freshly dispersed type 1 (lane 2 ) and type 2 (lane 3 ) cells using primers for SM22. The first lane is a DNA ladder indicating the expected product size of $280 \mathrm{~kb}$. Note that both type 1 and 2 cells contain mRNA for SM22. (C) Polyacrylamide gel of a cell extract of type 1 cells after 2 (left lane) or $7 \mathrm{~d}$ (right lane) in culture. Only that portion of the gel showing myosin heavy chain isoforms is included. Note that at both times in culture muscle ( $S M-1$ and $S M-2)$ and nonmuscle $(n m M Y O)$ myosin heavy chains are present and their levels of expression do not change with time in culture. The presence of both muscle and nonmuscle myosin is consistent with immunohistochemical data (Fig. 4).

cells did not express smooth muscle myosin heavy chain or alpha actin (Fig. 5) immediately ( $8 \mathrm{~h}$ ) after isolation; however, nonmuscle myosin heavy chain was expressed at all times. With time in culture, type 2 cells expressed increasing amounts of smooth muscle alpha actin which became organized into stress fibers (Fig. 5), but expression of smooth muscle myosin heavy chain was not detected. The expression of nonmuscle myosin heavy chain remained constant. These results are summarized in Table III along with additional immunohistochemical results using antibodies to vimentin and the Na pump.

Through the use of Northern analysis or PCR, the above results were confirmed and extended (Fig. 6, $A$ and $B$ ). A cDNA specific for smooth muscle myosin heavy chain labeled RNA from freshly isolated type 1 cells but not RNA from freshly isolated or cultured type 2 cells (Fig. $6 \mathrm{~A}$ ). The presence of SM22 mRNA, a putative Ca-binding protein characteristic of differentiated VSMC (24), was detected by Northern analysis in freshly isolated type 1 cells and confluent type 2 cells, but not in freshly isolated type 2 cells. PCR amplification indicated the presence of SM22 mRNA in all samples (Fig. 6 $B$ ), suggesting that under appropriate conditions type 2 cells could be induced to express elevated levels of SM22 mRNA (i.e., at confluence).
We next asked whether type 1 and type 2 cells could be identified in vivo, and, if so, were they homogeneously distributed throughout the vessel wall or localized in specific regions as the differential digestion studies suggested. From the above immunohistochemical studies freshly isolated type 1 cells could be differentiated from freshly isolated type 2 cells by their expression of both smooth muscle alpha actin and myosin heavy chain. Using these criteria, the presence and distribution of type 1 and 2 cells in full thickness cryosections of canine carotid arteries were determined. These data are presented in Fig. 7. In Fig. 7, $A-D$, high $(A-C)$ and low $(D)$ power images of a carotid artery cryosection labeled with the smooth muscle myosin heavy chain antibody (red) and the nuclear stain DAPI (blue) are shown. Coincident labeling by the myosin antibody and DAPI resulted in nuclei that are white. The great majority of cells within the media reacted positively to the smooth muscle myosin heavy chain antibody as indicated by the extent of red labeling and the large number of white nuclei. Most of these cells appear to be oriented circumferentially since their nuclei appear elongated (Fig. 7, $A-C$ ). Identical results were obtained using the smooth muscle alpha actin antibody (data not shown). However, cells negative for smooth muscle myosin heavy chain, indicated by blue nuclei, were seen along the lumen in the intimal layer, outside of the media in the adventitial layer as well as in the medial layer (Fig. 7, $A-D$ ). The muscle protein-negative cells within the media could be seen in the elastic lamina (Fig. 7, $A-C$ ) and appeared organized into bands as evident when cells positive to only DAPI are displayed (Fig. 7 E). These cells had nuclei that were smaller and more irregularly shaped than the cells that were myosin positive. These two nuclear morphologies could also be observed even in routine histological sections (Fig. 7, $F$ and $G$ ). Examination of cells within and adjacent to the elastic lamina indicated that cells within the elastic lamina were negative to smooth muscle myosin heavy chain (Fig. $7 \mathrm{H}$ ) and alpha actin (Fig. $7 \mathrm{~J}$ ) but positive to nonmuscle myosin heavy chain (Fig. 7 I). Cells adjacent to the elastic lamina were positive to both muscle and nonmuscle myosin heavy chains (Fig. 7, $H$ and $I$ ) and alpha actin (Fig. $7 \mathrm{~J}$ ). Taken together, these data suggest that the dominant cell within the media is type 1 while that in the adventitia is type 2 . However, type 2 cells are not restricted to the adventitial layer for they are also seen within the media.

To determine if cells forming the neointima were more similar to type 1 or type 2 cells, balloon catheter-induced deendothelialization was performed and the immunohistochemical characteristics of the neointimal cells were determined in situ and in culture. A definite neointima was observed within $7 \mathrm{~d}$ after deendothelialization (Fig. 8) which increased in thickness at $14 \mathrm{~d}$ (Fig. 9). At $7 \mathrm{~d}$ after injury, cells within the neointima were positive to antibodies to smooth muscle alpha actin and nonmuscle myosin heavy chain but not to smooth muscle myosin heavy chain (Fig. 8). The relative intensity of this labeling did not change between 1 and 2 wk after deendothelialization (data not shown). Cells within the media of injured vessels had the same antibody labeling characteristics as cells within the media of normal vessels.

Cells isolated by timed enzymatic digestions from the lumenal surface of a vessel $14 \mathrm{~d}$ after injury were compared with cells from the contralateral control carotid (Fig. 9). Cells obtained from the first enzyme digestion $(\sim 15 \mathrm{~min})$ of the injured vessel yielded small spherical cells that attached readily to the culture dish, spread, and proliferated (Fig. 9). When ex- 

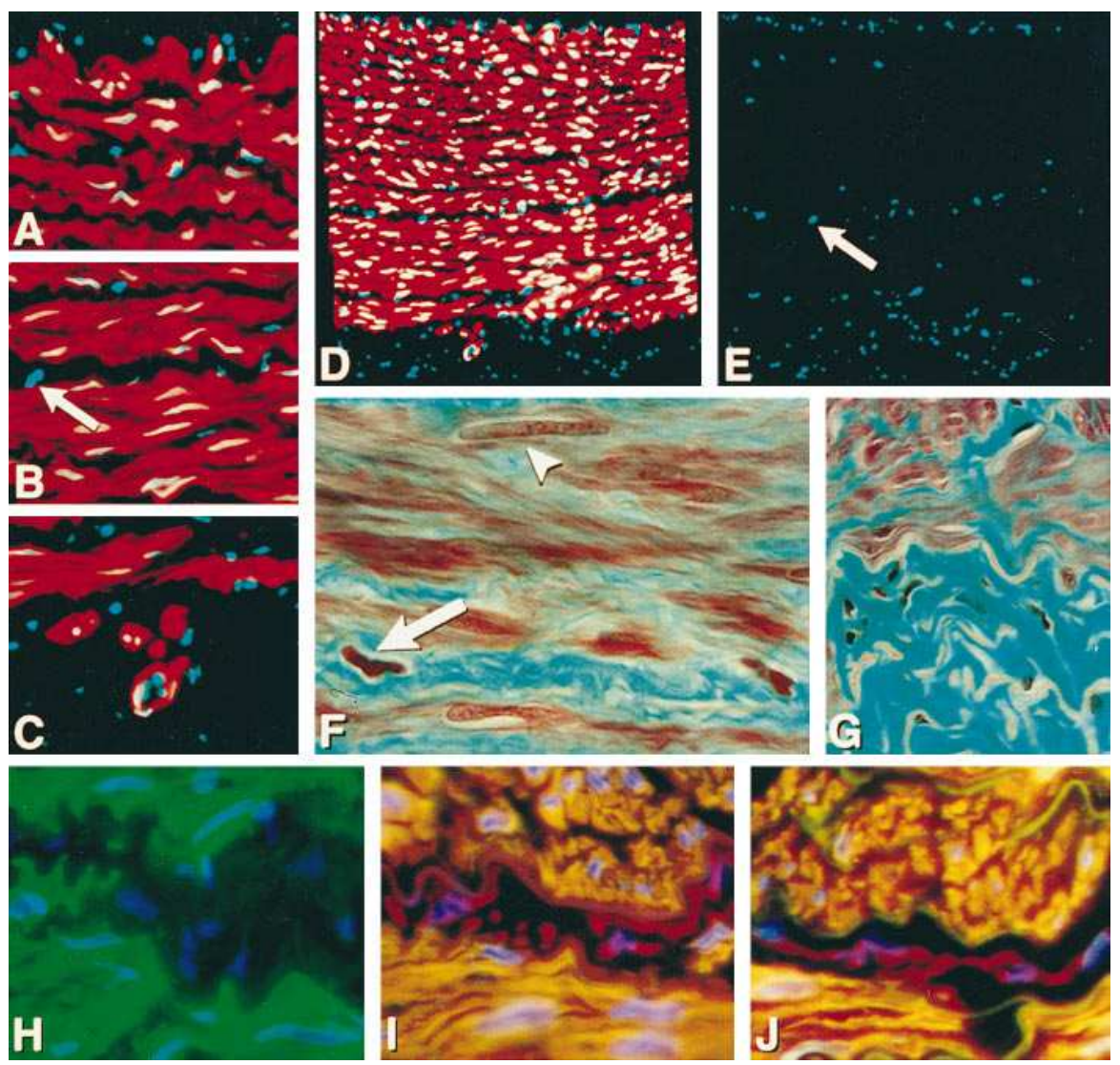

Figure 7. Photomicrographs of antibodylabeled normal carotid artery cryosections $(A-E$ and $H-J)$ and trichromestained histological sections ( $F$ and $G$ ). $A-D$ are digitized pseudocolored images of a section double labeled with an antibody to smooth muscle myosin heavy chain and the nuclear stain, DAPI. Myosin-positive cells are pseudocolored red. Nuclei of myosin-negative cells are blue while those of myosin-positive cells are white. $A-C$ highlight various areas (lumen to adventitia) of the whole wall shown in $D$. Note that some cells within the media are negative to smooth muscle myosin, as indicated by the presence of blue nuclei. $E$ is the same section as $D$ but showing only the blue nuclei of myosin-negative cells. Arrows in $B$ and $E$ point to the same cell. Note that these myosin-negative cells appear to be organized into discrete bands throughout the media. The additional characteristics of cells within these layers are illustrated in the digitized pseudocolored images of panels $H-J$ : $H$, cells labeled with smooth muscle myosin antibody (green) and DAPI (blue); $I$, cells labeled with smooth (green) and nonmuscle myosin (red) antibodies and DAPI (blue); and $J$, cells labeled with alpha actin (green) and nonmuscle myosin (red) antibodies and DAPI (blue). Coincident labeling of cells with the nonmuscle antibody and either

myosin $(I)$ or alpha actin $(J)$ antibody results in a yellow color. Note that cells within the adventitial layer and the medial interlamellar spaces are negative for smooth muscle myosin and actin $(A-C, H$, and $J)$ but positive for nonmuscle myosin $(I$ and $J)$. Even routine histological sections $(F$ and $G$ ) reveal cells with distinct nuclear morphologies within the interlamellar spaces $(F)$ and the adventitia $(G)$. Arrowhead in $F$ points to an elongated nucleus of a smooth muscle myosin- and actin-positive cell (see elongated white nuclei in $A-D$ ) while the arrow points to a cell negative to smooth muscle markers.

amined $8 \mathrm{~h}$ after seeding, these cells reacted positively to the smooth muscle alpha actin antibody (Fig. 9) but were negative to the smooth muscle myosin heavy chain antibody (data not shown). Subsequent digestions yielded primarily large bipolar cells until the adventitial surface was approached when small spherical cells increased in number. In contrast, cells obtained during the first 15 min of digestion from the contralateral control carotid artery were large bipolar cells that did not spread or proliferate. Based on immunocytochemical and culture characteristics, neointimal cells were more similar to cultured type 2 cells (see Fig. 4 ) than to type 1 cells. The characteristics of cells in vivo are summarized in Table III.

To determine if type 1 and 2 cells were unique to canine carotid arteries, cryosections of canine saphenous vein were also examined (Fig. 10). Both cell types could be identified by their characteristic cross-reactivity with smooth muscle alpha actin and myosin heavy chain antibodies and, as in the carotid artery, type 1 and 2 cells were present within the media, while only type 2 cells were observed in the adventitia.

\section{Discussion}

Immunohistochemical characterization of canine carotid artery and saphenous vein indicates the presence of at least two distinct cell types (type 1 and 2) based on their expression of smooth muscle actin and myosin. Type 1 cells expressed smooth muscle alpha actin and myosin heavy chain while type 2 cells did not (Fig. 7 and Table III). Those cells expressing muscle proteins (type 1) were restricted to the medial layer and represented the majority of cells in this layer. Cells not expressing muscle proteins (type 2) were the sole cells in the adventitial layer but were also found within the media, sometimes organized into circumferential bands (Fig. 7).

Sequential digestion of the carotid artery also yielded two major cell populations that had the same immunohistochemical characteristics as the cell populations identified in situ (Table III). The relative yields of the two cell populations were dependent upon whether enzyme digestion was begun from the lumenal or adventitial surfaces of the vessel wall. Type 1 cells were in highest concentration in lumenal digests. Freshly isolated type 1 , but not type 2 cells, expressed mRNAs for smooth muscle myosin heavy chain and SM22 (Fig. 6, Table II), two markers suggested to be characteristic of differentiated smooth muscle cells (24). Finally, the two populations had very distinct morphologies when isolated. Those expressing muscle proteins (type 1) were large and bipolar (Figs. 1-3) while those cells not expressing muscle proteins (type 2) were small and spherical (Figs. 1 and 3). Based on these characteris- 
phase-contrast neointima
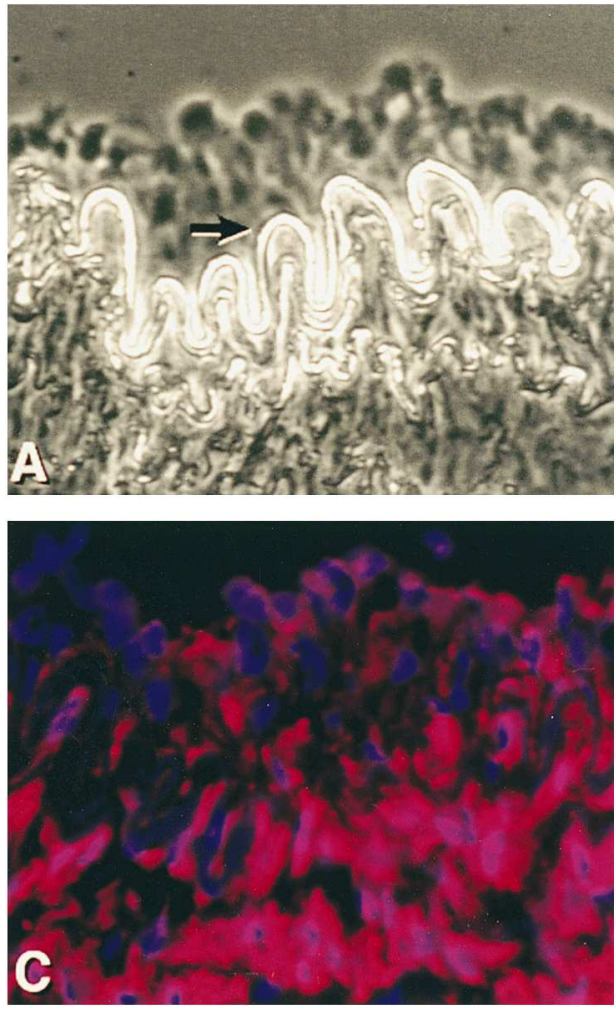

$(\iota$-actin

tics, the type 1 cells are considered to be differentiated VSMC while the type 2 cells are of unknown origin.

The identity of type 2 cells is unclear but similar cells have been described by Moss and Benditt (3) in the media of adult avian aorta and more recently by Frid et al. (25) in adult bovine pulmonary artery. The type 2 cell most closely corresponds to the L3i cell of Frid et al. (25) based on common immunohistochemical characteristics and location within the vessel wall. The L3i cell expressed muscle proteins in late fetal and neonatal life but not in the adult, suggesting that they have a smooth muscle origin. The expression of smooth muscle alpha actin (Fig. 5) and the presence of mRNA for SM22 (Fig. 6) in cultured type 2 cells suggest that they, too, may be of muscle origin. The presence of type 2 cells within the media of canine saphenous vein (Fig. 10) suggests that they are not unique to the carotid. These data clearly demonstrate that conduit vessels from large mammals have a media composed of a heterogeneous cell population.

When VSMC were placed in culture they attached well to a collagen substratum (Fig. 1) but poorly to glass or tissue culture plastic. However, this attachment did not promote cell spreading (Fig. 3), a prerequisite for cell migration. Even though VSMC did not proliferate (Table I), they were considered viable because they were selectively permeable to specific markers (trypan blue, ethidium homodimer, calcein AM) and exhibited regulated Na pump activity (Table II). Finally, VSMC did not qualitatively change their expression of smooth muscle alpha actin or myosin heavy chain over $1 \mathrm{wk}$ in culture (Fig. 4). These data imply either that standard tissue culture conditions are inadequate to induce mitogenesis and phenotypic modulation of isolated canine carotid VSMC or that these cells are terminally differentiated.

\section{sm-mhc}

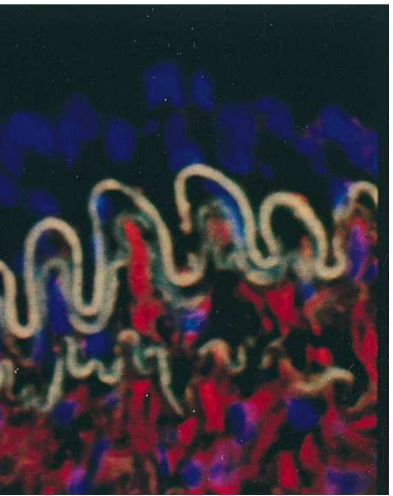

Figure 8. Photomicrographs of the neointimal layer of carotid artery 1 wk after deendothelialization with a balloon catheter. Sections labeled with antibodies to smooth muscle $(s m-m h c)$ and nonmuscle myosin $(n m-m h c)$ heavy chains or smooth muscle alpha actin plus the nuclear stain, DAPI (blue). Arrow in phasecontrast image $(A)$ indicates the internal elastic lamina. Note that neointimal cells are negative for smooth muscle myosin $(B)$ but positive to smooth muscle alpha actin $(C)$ and nonmuscle myosin $(D)$ antibodies.

$\mathrm{nm}-\mathrm{mhc}$
In contrast, the canine carotid type 2 cells exhibited protrusive membrane activity typical of motile cells (Figs. 1 and 3), incorporated thymidine (Table I), and increased their expression of smooth muscle alpha actin with time in culture (Fig. 5). Type 2 cells appeared more sensitive to low $(0.5 \%)$ than to high serum concentrations $(10 \%)$ even though these values were not statistically different. This could be an intrinsic property of type 2 cells. Differences in serum sensitivity between arterial cells isolated from a variety of species have been reported by many laboratories (26-28) but few have reported a greater mitogenic effect of low serum concentrations (28). Alternatively, the effectiveness of $0.5 \%$ serum may be due to the use of primary cultures. Most growth studies use passaged cells maintained in serum-containing medium. Type 2 cells in this study were primary cultures, first exposed to serum at the time of thymidine incorporation. If growth factor receptor desensitization occurs upon exposure to high serum concentrations, the naive state of the cells combined with desensitization could make the response to low serum greater than to high serum. Additional experiments need to be performed to test this hypothesis.

Assuming that exposure of cultured cells to serum mimics in many ways the proliferative and phenotypic modulation response of vascular cells during in vivo remodeling, the above cellular characterizations suggest that type 2 cells, rather than VSMC, would more likely be responsible for neointimal formation in response to deendothelialization. This was tested by immunohistochemical characterization of carotid neointimal cells in situ and in culture.

Neointimal cells 7 and $14 \mathrm{~d}$ after balloon catheter injury expressed smooth muscle alpha actin and nonmuscle myosin heavy chain in situ but not smooth muscle myosin heavy chain 


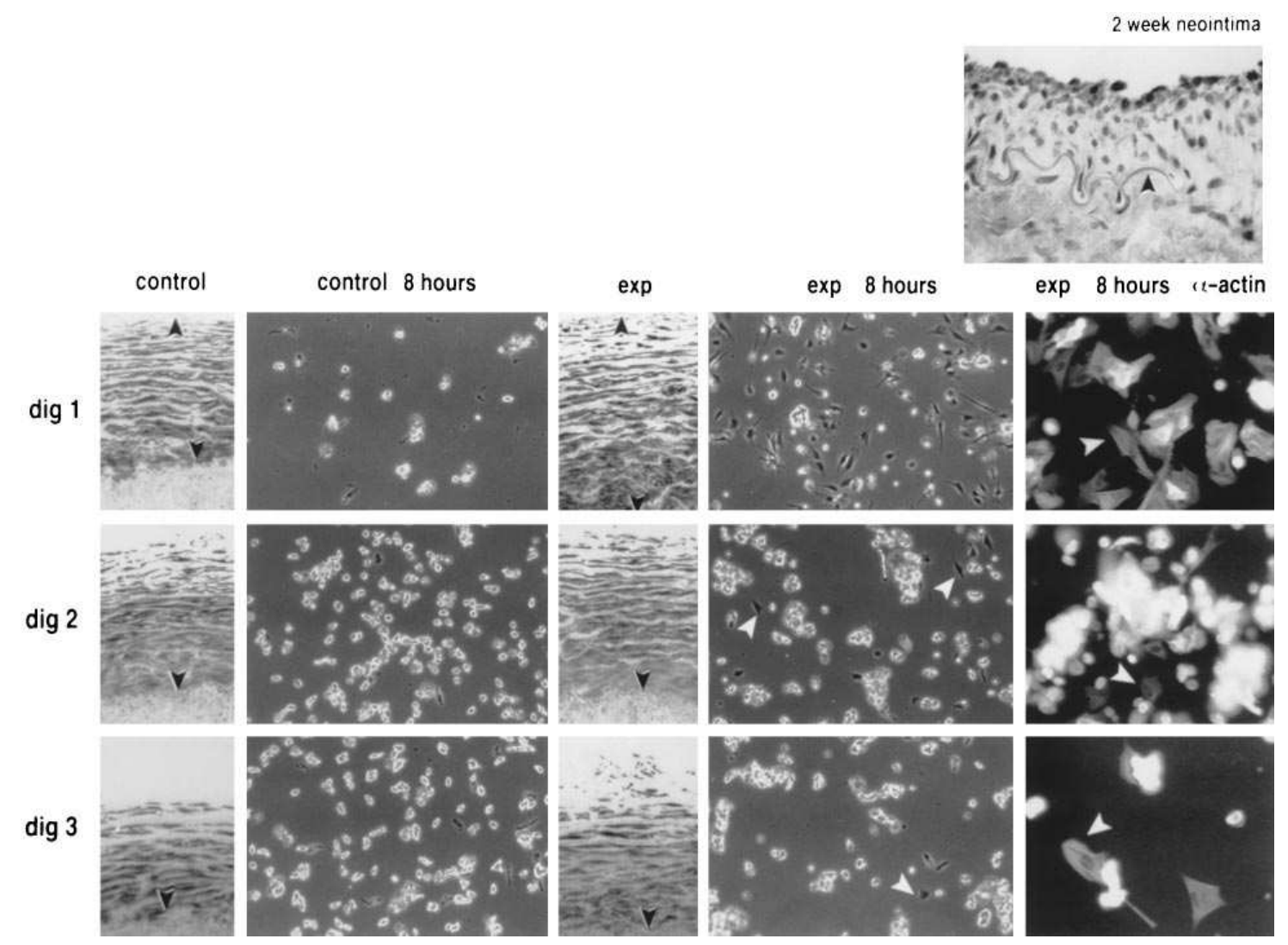

Figure 9. Photomicrographs of histological sections and cells released by three sequential 15-min enzyme digestions from everted uninjured (control) and injured (exp, injured $2 \mathrm{wk}$ before) contralateral carotid arteries. Black arrowheads in histological sections mark the extent of the medial layer. Released cells were studied $8 \mathrm{~h}$ after isolation. The first 15-min digestion $(\operatorname{dig} 1)$ released a large number of cells from the injured vessel (exp 8 hours) many of which rapidly spread in culture (control 8 hours vs. exp 8 hours) and were positive to the smooth muscle actin antibody (white arrowhead, exp 8 hours $\alpha$-actin). Continued digestions (dig 2 and dig 3 ) also released more spreading (white arrowheads, exp 8 hours), actin-positive (white arrowhead, exp 8 hours $\alpha$-actin) cells from the experimental vessel than from the control vessel (compare with Fig. 5). Alpha actin labeling of cells released from the control vessel was identical to that illustrated in Fig. 5.

(Fig. 8). Neointimal cells isolated from an artery 2 wk after injury also expressed these proteins shortly after isolation $(8 \mathrm{~h})$ and, when placed in culture spread on glass or collagen substrata, proliferated and continued to express smooth muscle alpha actin (Fig. 9). Based on the parameters assessed in these experiments, neointimal cells in situ and in culture are indistinguishable from type 2 cells that have been in culture for three or more days (Fig. 5). Therefore, these data suggest that it is the type 2 cell that forms the neointima in the injured canine carotid artery rather than the VSMC. The most likely source of type 2 cells that form the neointima are those cells within the media nearest the lumen (Figs. 7 and 8).

Two observations in this study appear to stand in contrast to observations made by other investigators using cultured vascular cells from rat and rabbit arteries. These observations are: (a) the isolation of VSMC that do not proliferate or undergo phenotypic modulation in culture; and $(b)$ the isolation of a cell that is initially negative to smooth muscle alpha actin but which expresses actin with time in culture (type 2 cells). These observations may not have been reported previously for a variety of reasons: $(a)$ the isolation of more homogeneous cell populations because of timed enzymatic digestion in one direction through the vessel wall; $(b)$ the use of the canine carotid artery; $(c)$ the differential substrate adhesive properties of VSMC and type 2 cells; and $(d)$ the morphological and immu- nohistochemical characterization of cells shortly after isolation. The use of timed digestions to disperse cells beginning from either the lumenal or adventitial surfaces may have resulted in more homogeneous cell suspensions. This may also have been aided by selection of the carotid artery which has fewer type 2 cells within the media than the saphenous (Figs. 7 and 10), for example, and, therefore, may have fewer than rat or rabbit arteries. In other published studies minced pieces of

Table III. Immunohistochemical Characteristics

\begin{tabular}{|c|c|c|c|c|c|c|}
\hline & \multicolumn{3}{|c|}{ Isolated cells } & \multicolumn{3}{|c|}{ Cryosections } \\
\hline & Type 1 & Type 2 & $\begin{array}{c}\text { Type } 2 \\
\text { confluent }\end{array}$ & VSMC & Type 2 & $\begin{array}{c}\text { Neointima } \\
2 \mathrm{wk}\end{array}$ \\
\hline Alpha actin & + & - & + & + & - & + \\
\hline smMHC & + & - & - & + & - & - \\
\hline $\mathrm{nmMHC}$ & + & + & + & + & + & + \\
\hline Vimentin & + & + & + & + & + & + \\
\hline Na pump & + & + & + & + & + & + \\
\hline
\end{tabular}

Summary of immunohistochemical characteristics of isolated cells and cells in situ. $s m M H C$, smooth muscle myosin heavy chain; $n m M H C$, nonmuscle myosin heavy chain. 

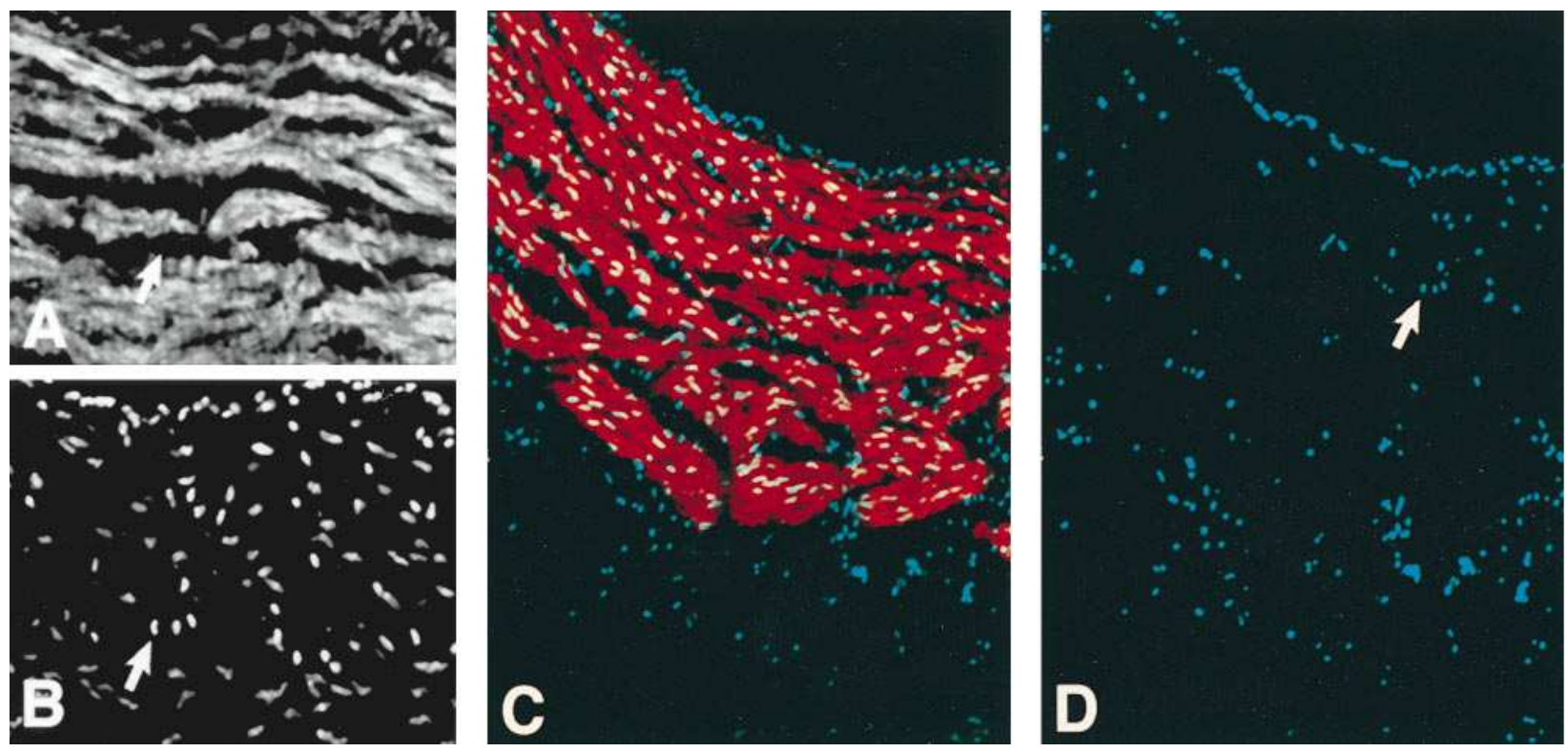

Figure 10. Digitized images of a cryosection of canine saphenous vein doubled labeled with an antibody to smooth muscle alpha actin and the nuclear stain DAPI. $A$ shows the pattern of actin labeling in a portion of the media while $B$ shows the distribution of nuclei in the same area. The arrows point to cells negative to alpha actin. $C$ is a pseudocolored image of the whole wall with red indicating actin labeling, blue indicating nuclei of cells negative to actin, and white indicating nuclei of cells positive to actin. $D$ illustrates only the nuclei of actin-negative cells. The arrow points to the same cells indicated in $A$ and $B$. As in carotid arteries, the saphenous vein also contains cells within the medial and adventitial layers that are negative for smooth muscle alpha actin and myosin.

aortic media or whole wall were digested $(8,10-12$, and 29$)$ to obtain cells for study. This most likely results in a heterogenous cell suspension since evidence indicates that the aortic media is not homogeneous (8-12). If, in addition, one cell type does not proliferate rapidly and adheres poorly to tissue culture plastic while another proliferates rapidly and adheres well, the latter population would eventually dominate the culture. It is a general observation that seeding efficiency for primary smooth muscle cultures is poor compared with passaged cells. This may be because the primary cell isolate contains a high proportion of cells (e.g., VSMC) that have weaker adhesive properties and are subsequently lost. Such shifts in cell population with time in culture would also appear as phenotypic modulation if the cells expressed different proteins at isolation. The presence of alpha actin-negative cells has been reported in freshly isolated rat aortic cells $(10,11)$ suggesting the presence of type 2 cells in this vessel; however, the ability of such cells to express alpha actin with time in culture was not determined. Based on in situ data (8-12), type 2 cells have been identified in the media of rat and rabbit vessels and should be present in dispersed cell preparations. Therefore, it is very likely that the two cell types identified in canine carotid artery and saphenous vein are present in vessels from other species. Additional experiments will have to be performed to confirm this suggestion.

The possibility that VSMC are terminally differentiated is consistent with other muscle cell types. In skeletal muscle, the products of myogenic determinant genes, such as myoD, appear to control the differentiation of myoblasts into fused myotubes, the expression of contractile proteins, and the blockade of cell division (30). Once initiated to differentiate, the myoblast becomes committed and loses the ability to proliferate or dedifferentiate. Introduction of the gene for myoD into cultured rat aortic cells or into nonmuscle cells resulted in the expression of skeletal muscle genes for myosin and alpha actin only in aortic cells (31). Recently, a potential antiproliferative gene unique to vascular smooth muscle, Gax, has been identified in rat aortic cells. Gax is upregulated during growth arrest in culture (32), which is a time when contractile proteins characteristic of the differentiated state are reexpressed $(29,33)$. These studies indicate that vascular cells contain and can respond to gene products associated with terminal differentiation. Wohrley et al. (34) have demonstrated in neonatal bovine pulmonary arteries that hypoxia induces extensive cell proliferation except in an anatomically distinct population of differentiated VSMC. Either these VSMC are not sensitive to the proliferative effects of hypoxia or they are incapable of entering the cell cycle. These in vivo observations suggest that the isolation of postmitotic VSMC is possible.

In conclusion, these studies demonstrate that the media of canine vessels is composed of at least two cell populations. One population, VSMC, expresses characteristic muscle proteins, is restricted to the media, and does not proliferate when placed in culture. A second population, type 2 cells, is devoid of muscle contractile proteins in vivo, and is primarily in the adventitia but can also be found within the media. This second population is capable of proliferating and expressing smooth muscle alpha actin in culture. These are characteristics of cells found within the neointima of injured carotid artery. Taken together, these observations suggest that the canine carotid VSMC is incapable of forming the neointima and that the neointima is formed by the type 2 cell.

\section{Acknowledgments}

The authors wish to acknowledge the intellectual contributions made by Dr. Mark Entman and Dr. Mark Majesky, and the secretarial assistance provided by Ms. Corneille Smith. 
This study was supported by grants from the American Heart Association (91013100) and the National Institutes of Health (HL-24585 and HL-42550).

\section{References}

1. Pease, D.C., and W.J. Paule. 1960. Electron microscopy of elastic arteries. The thoracic aorta of the rat. J. Ultrastruct. Res. 3:469-483.

2. Lauper, N.T., K.K. Unni, B.A. Kottke, and J.L. Titus. 1975. Anatomy and histology of aorta of white carneau pigeon. Lab. Invest. 32:536-551.

3. Moss, N.S., and E.P. Benditt. 1970. Spontaneous and experimentally induced arterial lesions. I. An ultrastructural survey of the normal chicken aorta. Lab. Invest. 22:166-183.

4. Wissler, R.W. 1968. The arterial medial cell, smooth muscle of multifunctional mesenchyme? J. Atheroscler. Res. 8:201-213.

5. Campbell, G.R., J.H. Campbell, J.A. Manderson, S. Horrigan, and R.E. Rennick. 1988. Arterial smooth muscle: a multifunctional mesenchyme cell. Arch. Pathol. Lab. Med. 112:977-986.

6. Ross, R., and J.A. Glomset. 1973. Atherosclerosis and the arterial smooth muscle cell. Proliferation of smooth muscle is a key event in the genesis of the lesions of atherosclerosis. Science (Wash. DC). 180:1332-1339.

7. Kocher, O., O. Skalli, W.S. Bloom, and G. Gabbiani. 1984. Cytoskeleton of rat aortic smooth muscle cells: normal conditions and experimental intimal thickening. Lab. Invest. 50:645-651.

8. Zanellato, A.M.C., A.C. Borrione, M. Tonello, G. Scannapieco, P. Pauletto, and S. Sartore. 1990. Myosin isoform expression and smooth muscle cell heterogeneity in normal and atherosclerotic rabbit aorta. Arteriosclerosis. 10: 996-1009.

9. Zanellato, A.M.C., A.C. Borrione, L. Giuriato, M. Tonello, G. Scannapieco, P. Pauletto, and S. Sartore. 1990. Myosin isoforms and cell heterogeneity in vascular smooth muscle. I. Developing and adult bovine aorta. Dev. Biol. 141:431-446.

10. Skalli, O., W.S. Bloom, P. Ropraz, B. Azzarone, and G. Gabbiani. 1986. Cytoskeletal remodeling of rat aortic smooth muscle cells in vitro: relationships to culture conditions and analogies to in vivo situations. J. Submicrosc. Cytol. 18:481-493.

11. Skalli, O., P. Ropraz, A. Trzeciak, G. Benzonana, D. Gillessen, and G. Gabbiani. 1986. A monoclonal antibody against $\alpha$-smooth muscle actin: a new probe for smooth muscle differentiation. J. Cell Biol. 103:2787-2796.

12. Bochaton-Piallat, M.-L., F. Gabbiani, P. Ropraz, and G. Gabbiani. 1992. Cultured aortic smooth muscle cells from newborn and adult rats show distinct cytoskeletal features. Differentiation. 49:175-185.

13. Gordon, D., M.A. Reidy, E.P. Benditt, and S.M. Schwartz. 1990. Cell proliferation in human coronary arteries. Proc. Natl. Acad. Sci. USA. 87:46004604.

14. Björkerud, S., K. Gustavsson, and M. Hasselgren. 1984. In vitro cultivation of rabbit aortic media and the development of the cultures in relation to cellular heterogeneity. Acta Pathol. Microbiol. Immunol. Scand. Sect. A Pathol. 92:113-124.

15. Björkerud, S. 1984. Separation of arterial smooth muscle cell subpopulations with different growth patterns. Acta Pathol. Microbiol. Immunol. Scand. Sect. A Pathol. 92:293-301.

16. Majesky, M.W., and S.M. Schwartz. 1990. Smooth muscle diversity in arterial wound repair. Toxicol. Pathol. 18:554-559.

17. Warshaw, D.M., J.L. Szarek, and M.S. Hubbard. 1986. Pharmacology and force development of single freshly isolated bovine carotid artery smooth muscle cells. Circ. Res. 58:399-406.

18. Schildmeyer, L.A., and C.L. Seidel. 1989. Quantitative and qualitative heterogeneity in smooth muscle myosin heavy chains. Life Sci. 45:1617-1625.

19. Seidel, C.L., V. White, C. Wallace, J. Amann, D. Dennison, L.A. Schildmeyer, B. Vu, J.C. Allen, L. Navarro, and S. Eskin. 1988. Effect of seeding density and time in culture on vascular smooth muscle cell proteins. Am. J. Physiol. 254(Cell Physiol. 23):C235-C242.

20. Pressley, T.A. 1992. Phylogenetic conservation of isoform-specific regions within alpha-subunit of $\mathrm{Na}^{+}-\mathrm{K}^{+}$-ATPase. Am. J. Physiol. 262:C743-C751.

21. Nagai, R., M. Kuro-o, P. Babij, and M. Periasamy. 1989. Identification of two types of smooth muscle myosin heavy chain isoforms by cDNA cloning and immunoblot analysis. J. Biol. Chem. 264:9734-9737.

22. Nishida, W., Y. Kitami, and K. Hiwada. 1993. cDNA cloning and mRNA expression of calponin and SM22 in rat aorta smooth muscle cells. Gene (Amst.). 130:297-302.

23. Allen, J.C., S.S. Navran, C.L. Seidel, D.K. Dennison, J.M. Amann, and S.K. Jemelka. 1989. Intracellular Na regulation of Na pump sites in cultured vascular smooth muscle cells. Am. J. Physiol. 256:C786-C792.

24. Shanahan, C.M., P.L. Weissberg, and J.C. Metcalfe. 1993. Isolation of gene markers of differentiated and proliferating vascular smooth muscle cells. Circ. Res. 73:193-204.

25. Frid, M.G., E.P. Moiseeva, and K.R. Stenmark. 1994. Multiple phenotypically distinct smooth muscle cell populations exit in the adult and developing bovine pulmonary arterial media in vivo. Circ. Res. 75:669-681.

26. Fujita, H., K. Shimokado, C. Yutani, S. Takaichi, J. Masuda, and J. Ogata. 1993. Human neonatal and adult vascular smooth muscle cells in culture. Exp. Mol. Pathol. 58:25-39.

27. Lemire, J.M., C.W. Covin, S. White, C.M. Giachelli, and S.M. Schwartz. 1994. Characterization of cloned aortic smooth muscle cells from young rats. Am. J. Pathol. 144:1068-1081.

28. Schwartz, S.M., L. Foy, D.F. Bowen-Pope, and R. Ross. 1990. Derivation and properties of platelet-derived growth factor-independent rat smooth muscle cells. Am. J. Pathol. 136:1417-1428.

29. Rovner, A.S., R.A. Murphy, and G.K. Owens. 1986. Expression of smooth muscle and nonmuscle myosin heavy chains in cultured vascular smooth muscle cells. J. Biol. Chem. 261:14740-14745.

30. Wintraub, H., R. Davis, S. Tapscott, M. Thayer, M. Krause, R. Benezra, T.K. Blackwell, D. Turner, R. Rupp, S. Hollenberg, et al. 1991. The myoD gene family: nodal point during specification of the muscle cell lineage. Science (Wash. DC). 251:761-766.

31. van Neck, J.W., J.J. Medina, C. Onnekink, P.F.M. van der Ven, H.P.J. Bloemers, and S.M. Schwartz. 1993. Basic fibroblast growth factor has a differential effect on MyoD conversion of cultured aortic smooth muscle cells from newborn and adult rats. Am. J. Pathol. 143:269-282.

32. Gorski, D.H., D.F. LePage, C.V. Patel, N.G. Copeland, N.A. Jenkins, and K. Walsh. 1993. Molecular cloning of a diverged homeobox gene that is rapidly down-regulated during the $\mathrm{G}_{0} / \mathrm{G}_{1}$ transition in vascular smooth muscle cells. Mol. Cell. Biol. 13:3722-3733.

33. Babij, P., S. Kawamoto, S. White, R.S. Adelstein, and M. Periasamy. 1992. Differential expression of SM1 and SM2 myosin isoforms in cultured vascular smooth muscle. Am. J. Physiol. 262(Cell Physiol. 31):C607-C613.

34. Wohrley, J.D., M.G. Frid, E.P. Moiseeva, E.C. Orton, J.K. Belknap, and K.R. Stenmark. 1995. Hypoxia selectively induces proliferation in a specific subpopulation of smooth muscle cells in the bovine neonatal pulmonary arterial media. J. Clin. Invest. 96:273-281. 